\title{
SOME ASPECTS OF FORMATION OF JUNIOR BACHELOR HAVING LEGAL COMPETENCE: HIGHER EDUCATION RESOURCES
}

\section{Yaroslav Kichuk $^{1}$ Olena Litinska ${ }^{2}$}

\section{DOI: https://doi.org/10.30525/978-9934-588-39-6-7}

Introduction. Transition of Ukraine to new economic relations has brought about the need for the formation of a new model of the specialist capable of perceiving the mobility of market transformations, raising his/her own legal competence over a lifetime and having a formed high level of critical thinking.

Recent Research Analysis. The analysis of scientific sources shows that the efforts of the researchers are focused on the issue of quality of professional training of a future specialist and his/her legal competence. We take the position of researchers who think as follows: «Legal competence implies knowledge and implementation of social norms and rules of conduct that are sanctioned or established by the state in accordance with his/her rights, duties and powers» [2, p. 10] or «legal competence as a set of knowledge, beliefs, mind-set of personality, which are implemented in the process of work, communication, behaviour as well as attitudes to the material and spiritual values of society [15, p. 45]. It becomes obvious that a modern competitive specialist is distinguished by the ability to protect his/her natural, political, civil and social rights, which are exercised in the process of activity (work).

The problems of formation of legal consciousness, legal culture, legal education and upbringing in modern times are studied by A. Aleksieiev, P. Baranov, A. Ovchynnikov, T. Soloviova and others. The formation of legal competence of future specialists is researched by S. Hurin, Ya. Kichuk, O. Panova, I. Seriaieva, N. Sokolov and others. S. Ahranovskyi, I. Kaizer and others focus their attention on determining legal competence via activitybased approach. The issues of theories of critical thinking are studied both by foreign and domestic researchers (Guy Lefrançois, D. Kluster, D. Halpern, I. Voropai, I. Zahasheva, A. Tiahlo). The subject of the researchers' attention is the peculiarities of formation of critical thinking (L. Kyienko-Romaniuk, T. Noiel-Tsyhulskyi, D. Sharykova and others), L. Pirozhenko, O. Pometun, I. Piatakova and others investigate the pedagogical principles of the use of

\footnotetext{
${ }^{1}$ Izmail State Humanities University, Ukraine

${ }^{2}$ Izmail State Humanities University, Ukraine
} 
interactive technologies in higher educational institutions on the system level. However, the peculiarity of the process of becoming a student having a legal competence in higher educational institutions, who master a junior bachelor's degree, remains unaddressed by the modern researchers.

Objective: To prove the dominant importance of the cognitive aspect in the system of training of junior bachelors in higher educational institutions on the basis of systematization of scientific sources on the issues of legal competence, which promotes their formation as competitive professionals.

Presentation of basic material. The analysis of the legal and regulatory framework of the national higher education shows that the professional junior bachelor's degree is obtained at the level of professional pre-higher and higher education, which confirms the ability of a person to perform typical specialized tasks in a certain field of professional activity related to the fulfilment of challenging production tasks and performance of limited managerial functions and require the application of provisions and methods of a relevant field of science. Therefore, training of such a student is provided at the institutions of professional pre-higher education (college), vocational and technical education and higher education (subject to availability of a relevant license). Training on the level of higher education is possible according to the shortened program of training (short cycle). If we consider junior bachelors as an «educational product», it becomes clear that key competencies, professional and legal, are acquired at higher educational institutions. In particular, the guarantee of the legal literacy of professional junior bachelors of higher education is: firstly, the meaningful filling of the educational process; secondly, its forms and types of organization; thirdly, methods of teaching and, finally, the means of teaching junior bachelors. For practical application of key competencies of junior bachelors of higher education, sometimes, higher education professionals use various teaching methods: active, interactive, etc.

To interpret the concept of «legal competence» of junior bachelors, future specialists means to disclose its content at the highest level of generalization, by specifying the essential features:

- the genesis of the legal competence of the personality is contained in the plane of his/her legal and professional culture;

- legal competence is an integrative soft-and- professional feature of a future specialist;

- proceeding from the interrelation of the concepts of «competence», «competency», «key competence», we consider the legal competence of a personality as integrated one according to its nature and with available features of the «key» one (multi-functionality, multi-dimensionality, super subject and interdisciplinary nature), which is called forth, firstly, by an 
exceptional nature of managerial functions inherent to the law, both for the personality and for the society; secondly, by an integral manifestation over his/her lifetime, since social and legal aspects are always present in the process of interaction of a personality and society;

- legal competence is interpreted by us in the context of the concept of "personality activity»; having legal competence, the subject of this activity achieves its goals effectively showing mobility, orientation and critical thinking;

- legal competence is formed and manifested only in activity, it is exercised as a rights protective and enforcement one and can be active, destructive or passive, depending on the «threshold» of legal competence acquired by a future specialist («unconscious incompetence», "conscious incompetence», «unconscious competence», «conscious competence» - a starting threshold, at which it is predominantly possible and expedient to form this soft-and-professional feature with the student at the stage of his/her university professional education;

- legal competence as a formation has a component structure that is characterized by interrelation, interaction and mutual influence with the spirituality of the personality, his/her professional and legal culture; in this formation, the social content of the social consciousness is also reflected to a significant extent.

The self-reflection of teaching experience and the generalization of constructive practice convince us in the appropriateness of the process of legal competence formation of the future junior bachelor to comprehend in the context of the following stages: axiological, humanistic, cognitive, empirical, analytical and acmeological one. Thus, the cognitive component is the most significant one in terms of formative impact on the outcome, because it is represented by theoretical knowledge of law that can be used in practice by junior bachelors to successfully perform their professional responsibilities in their chosen specialty. However, along with the students' professional awareness in the aspect of theoretical knowledge, the ability to work with information meaningfully, to analyse, critically evaluate it during the educational activity of junior bachelors becomes no less significant. Learning activity becomes effective, if students are aware of their own learning process and reasonably apply the concepts of the cognitive sphere to understand the essence of a phenomenon, i.e. they organize the process of metacognition [1]. D. Halpern convincingly proves that a critically thinking person is characterized by a planning ability, flexibility of thinking, persistence, willingness to correct mistakes, comprehension of his/her own process of thinking and ability to compromise [5, p. 512]. No less significant in the context of the above is the research of an American educationalist D. Kluster, 
who identifies five basic points in the characteristic of critical thinking: firstly, it has an individual nature; secondly, information is a starting point, but not the ultimate point of critical thinking; thirdly, it starts with asking questions and clarifying the problems that need to be solved; fourthly, critical thinking seeks convincing argumentation... and, finally, fifthly, critical thinking is social thinking [3, p. 37]. Therefore, the priority in the work with junior bachelors of higher education is not only and not so much in the organization of the educational process, but in the involvement of the mental work load, which ensures the formation of critical thinking.

National practice proves that creative implementation of ideas embedded in constructive foreign experience and innovative teaching methods influences efficiently the formation of legal competence of junior bachelors, which has a significant number of advantages: they encourage the development of creative abilities, professional knowledge and critical thinking. In this plane, creative use of effective interactive methods (Ya. Ivanishch, O. Pometun, T. Remekh, V. Stadnik) deserves special attention, namely: the main methods of training are the work in small groups or in pairs, where the attitude to a specific life situation is determined (development and analysis of legal situations); comprehensive methods (imitation of a judicial proceedings or hearing in the case, «case-study», trainings, debates); auxiliary methods that give an opportunity to answer the questions or express one's opinion («open microphone», «Getting Acquainted»); gaming methods («range of ideas»). In the creative practice of teaching the legal subjects of a higher education institution, it is possible to use the INSERT technology - Interactive Noting System of Effective Reading and Thinking, which forms the cognitive component of legal competence. INSERT technology is an interactive text mark-up system for efficient reading and cogitativeness. It should be noted that this technology includes four stages, where the student is offered educational information that is independently entered into the matrix and labelled. An important step is to discuss the records entered by the student into the matrix. By systemizing the matrix, an opportunity is given to process a considerable amount of information, to come back to the initial notes, to recall what he/she knew on this topic earlier. Therefore, INSERT technology makes the process of information accumulation «visible», enables to process a considerable amount of information, promotes the development of critical thinking and encourages learning. At the same time, the teacher, by means of the table, can know the level of legal knowledge, motivation to acquire new educational information and available difficulties in understanding the legal terminology by the students.

Conclusions. Generalization of scientific sources proves that it is the cognitive component of critical thinking - an important segment of personal 
and professional feature that has a decisive influence on the formation of legal competence of junior bachelors of higher educational institutions through their productivity. It is about the possibilities of influence on the enrichment of this component by means of interactions (cases, trainings, debates), which contribute to the establishment of the foundations of legal culture, and therefore, is a factor of optimization of educational and professional activity of future junior bachelors.

\section{References:}

1. Lefrançois, Guy (2005). Prikladnaya pedagogicheskaya psikhologiya [Applied pedagogical psychology]. St. Petersburg: Piter, 120 p.

2. Gurin, S. V. (2005). Formirovaniye provovoy competentnosti budushchego uchitelya $v$ uchebno-vospitatelnom protsesse [Formation of legal competence of a future teacher in the educational process]: diss. cand. ped. nauk. Moscow, $40 \mathrm{p}$.

3. Kluster, D. (2001). Chto takoie kriticheskoie myshleniie? [What is critical thinking?]. Change: An international journal on the development of thinking through reading and writing. No. 4, pp. 36-40.

4. Kuzmenko, L. V. (2007). Formuvannia aktyvnoi hromadianskoi pozytsii vukhovantsiv shkil-internativ zasobamy uchnivskoho samovriaduvannia [Formation of Active Civic Position of Boarding Schoolers by Means of Pupils' Self-Government]. Formuvannia zhyttievoi kompetentnosti vukhovantsiv shkil-internativ [Formation of Life Competence of Boarding Schoolers]: Scientific- methodological manual / Head of the authors' team Sviridenko S. O., Vashchenko O. M. Kyiv, 49 p.

5. Ohorodniichuk, I. A. (2008). Diagnostika urovney pravovoy kompetentnosti [Diagnostics of the levels of legal competence]. Naukovyi Visnyk Pivdennoukrainskoho Derzhavnoho Pedahohichnoho Universytetu im. K.D. Ushynskoho [Scientific Bulletin of South Ukrainian State Pedagogical University named after K.D. Ushynsky]. Odesa, pp. 225-228.

6. Halpern, D. (2000). Psikhologiya criticheskogo myshleniya [Psychology of Critical Thinking] the 4th international ed. St. Petersburg: Piter, 512 p. 